\title{
THE IMPACT OF INVESTMENT DECISIONS ON FINANCIAL PERFORMANCE EMPIRICAL STUDY IN BANKING SECTOR OF IRAQ
}

\author{
Mohammed S. Ahmed ${ }^{1}$ and Ghadhanfer A. Hussein ${ }^{2}$ \\ ${ }^{1}$ Wasit University, Faculty of Economics \& Administration, Iraq \\ ${ }^{2}$ Middle Technical University, Baquba Technical Institute, Iraq \\ http://doi.org/10.35409/IJBMER.2022.3364
}

\begin{abstract}
The main purpose of the study is to gain a deeper understanding of how investment decisions affect the financial performance of the banking sector in Iraq and how in turn they affect their profits. to prove this, the quantitative approach was used, Al Rasheed Bank (Main Branch) has been chosen as a sample for study, and the questionnaire was adopted as an important tool for collecting data which numbered(102) distributed to its employees. statistically, AMOS version 25 and SPSS version 21 were adopted to investigate the patterns of relationships between variables under study. the analysis results indicated to there is a strong positive relationship, statistically significant between investment decisions and financial performance. In this context, several conclusions were reached, the most important of which is that investment decisions play a major role in improving the efficiency of financial performance by exploiting investment opportunities and reducing the level of risks through the optimal selection of invested assets.
\end{abstract}

Keyword: Investment Decisions, Financial Performance, AMOS, Banking sector.

\section{INTRODUCTION}

The modern business environment was characterized by a high level of complexity and dynamism until it became the feature of uncertainty and risks associated with the investment field are more than ever before. so, firm managers are should be careful about making their decisions to avoid risk and exploit investment opportunities (Zehir and Ozsahin,2008). and because of the importance of the financial sector and its effective contribution to enhancing economic activity in most of the countries, the banking system was chosen as a sample for study because it is considered one of the most important indicators of development in the financial sector(Pandey,2008). this is in turn, requires bank management to make efficient financial decisions are based on a group of recent concepts to contribute directly or indirectly in improving its financial performance levels, one of the most important of these concepts is financial knowledge in choosing the invested assets, as it plays a vital role in improving and rationalizing investment decisions, which will be positively reflected in the distribution of available financial resources on a variety of investment fields, which leads to achieving the highest possible level of profits with the lowest possible risk. Where investment decisions deal with the right side of the company's balance sheet in order to determine the optimal mix of assets, which means the funds invested in both current and fixed assets, and when they are determined, the financial manager works to determine the optimal level for each paragraph of the 


\section{International Journal of Business Management and Economic Review}

Vol. 5, No. 01; 2022

ISSN: 2581-4664

current assets and also decides the type of fixed assets that are acquired and when the fixed assets need to be modified, replaced or sold(Gitman et al,2015:442). the investment decision contributes to improving the financial performance of the company if the level of its returns is greater and the degree of its losses is less. This in turn leads to achieving the optimum return, which is a good indicator for investors and contributes to improving the market value of the company(Ross et al,2008:209).

\section{LITERATURE REVIEW}

\subsection{Investment Decisions}

Investment can be defined as the present obligation to spend money or other resources with the aim of obtaining future benefits (Zvi et al,2004). while (Simeyo et al,2013) defined investment as the spending of a money amount that is expected to generate a compensating future return that be more than for the original outlay plus a premium to cover inflation, interest foregone, and risk. as pointed out by (Sears and Trennepohl,1993) the person is faced with investment decisions when decides not to spend all their current income. according to (Riyanto, 2013:10) investment decisions are among the most important financial decisions because influence a return and risk hence affecting directly firm profitability taking into account the magnitude, opportunity, and risk of the future cash flows of investment (Ross et al, 2000). and it's reflected in the types of assets that are invested (Harjito \& Martono,2013:5). either in the tangible assets that include land, machinery factories among others, or in financial assets involving stocks, bonds, debts among others, and which considered their components the company's wealth (Riyanto, 2013:19). the structure of invested assets shows the quality and accuracy of investment decisions made and it is very important because it relates to the firm costs and the effective use of them leads it increased profits(Brigham \& Houston, 2006). (Vinci,2010) pointed out that the investment decision is related to different investment activities and the common goal is to invest money to enhance the wealth of the investors. In the same context, (Sumarsono, 2013: 39) (Brealey \& Myers, 2003) indicated there is vast evidence that references that the results of the right investment decisions will lead to optimal performance by increasing the growth of the company's assets and enable it to generate cash flows this will be reflected positively in stock prices. thus, it will contribute to attracting investors to invest their capital in its investment activities .therefore, the future success of an enterprise depends on its investment decisions (Bierman \& Smidt, 1993). investment decisions are made for several purpose: either for the purpose of expansion or renewal of investment projects or acquisition and merger of companies(Mintzberg et al,1976)(Ross et al, 2020:442).

\subsection{Financial Performance}

Financial performance is considered an indicator of a business model solidity level adopted by a firm and the extent of its efficiency in its management (Barringer and Ireland 2006) (Harjito \& Martono,2013:3). assessment of the company's financial performance is conducted over a period of time by analyzing its financial statements to determine its operating and financial characteristics, to statement how it's successful in achieving profitable revenue (Ross et al, 
Vol. 5, No. 01; 2022

ISSN: 2581-4664

2015). investors interact positively with the financial statements of companies with good performance, and this will lead to an increase in their investment in the company's shares, which leads to maximizing the company's value (Brigham and Jabinsky, 1997). Investors measure an organization's achievements in terms of its objectives, policies, and planned operations in monetary terms through its financial performance, thus these results reflect the company's ability to efficiently use its assets, its current stage of development, and potential growth and it show the financial position of the shareholders at the end of the period by using ratios primarily derived from the balance sheet and income statement, or using stock exchange price data. furthermore, stated (Gitman et al,2015:70) Good financial performance contributes to rationalizing the investment decision through the use of a set of financial indicators or ratios for the purpose of identifying the strengths and weaknesses in its financial performance so that the company can address the weaknesses and work to strengthen the strengths.

\subsection{The relationship between Investment decisions and the Financial Performance}

Like every business organization in the world, the banking sector in Iraq is not exempt from facing challenges when making investment decisions in terms of choosing the optimal mix of investments that leads to improving their financial performance (Ross et al., 2015: 11). Whereas (Harjito \& Martono, 2013: 3) indicated that the company's prosperity and the size of its paid profits are related to its ability to achieve profits from its investment activities. (Martono \& Harjito, 2003) Therefore financial performance is measured to assess the effectiveness and efficiency of the company in managing investments. We conclude from this that when investment is made in a variety of correct assets and the effective use of operational activities leads to maximum financial performance and thus improves the perception and perspective of investors about the value of the company, which increases the trading of its shares in the stock market, which leads to a rise in share prices and thus maximizes the wealth of owners and increased sale of newly issued shares(Mishkin,2004:43).

\section{RESEARCH METHODOLOGY}

\subsection{Study Problem}

Financial institutions in Iraq suffer from poor financial performance, especially in the banking sector, due to the lack of correct selection of the types of assets that will be invested and excessive investment in fixed-asset and capital mismanagement. In light of this, investment decisions were able to gain a large part of the researchers"e attention because they achieve optimal returns through the trade-off between return and risk when choosing assets for investment highly efficiently.

\subsection{Study Important}

The study endeavored to achieve the following points:

-Contribute to enabling banks to achieve the maximum possible profits.

-Raising awareness among financial managers of the importance of investment decisions by taking into account the return and the risk.

-Considering good financial performance as a positive indicator for investors. 
Vol. 5, No. 01; 2022

ISSN: 2581-4664

\subsection{Study Objectives}

This study is based on three main objectives, from which the study's trends revolve in identifying the nature of the relationship between the variables used in the study and these goals:

1-To know the nature of the relationship between investment decisions and Financial Performance?

2-To clearly identify the efficiency of investment decisions? 3- How do the shareholders view investment decisions?

\subsection{Study hypotheses}

There are two main hypotheses that have been derived from the available data, which contribute to the study of the main aspects of the study, as these hypotheses need to delve into the level of the statistical analysis used which shows the dependent variable and the independent variable. These hypotheses are:

H1: Is there a correlation of significant statistically significant between investment decisions and financial performance?

H2: Is there an impact of statistically significant and moral between investment decisions and financial performance?

\subsection{Study Sample}

The study sample consisted of (102) employees who were selected from the staff of AlRasheed Bank (the main branch) in Baghdad. (16) they work as department managers, (56) divisions officials, and (30) employees were selected from different departments.

\subsection{Data collection and analysis}

Data related to the theoretical aspect was collected through previous sources, books, and studies, while the questionnaire form was used as the main tool for collecting data related to the practical aspect. Previous studies were adopted in formulating the questionnaire. Where the questionnaire consists of two main variables, the independent variable (investment decisions) and it consists of 16 paragraphs approved by the study (Aburas and Hamid, 2013). while the dependent variable (financial performance) includes four sub-variables and includes 12 items adopted by (Saurabh et al, 2016) (Giovanni \& Vinzi, 2012). Data were analyzed by Amos software where AMOS was designed by the IBM team as a statistical package. AMOS uses ML estimation techniques in SEM analysis (Burne, 2010; Hare et al., 2010). 
Vol. 5, No. 01; 2022

ISSN: 2581-4664

\subsection{Research Framework}

Table (1): Research Framework

\begin{tabular}{|c|c|c|c|c|}
\hline \multicolumn{2}{|c|}{ Main Variables } & Sub-Dimensions & ID & $\begin{array}{c}\text { Item } \\
\text { No. }\end{array}$ \\
\hline \multirow{4}{*}{$\begin{array}{c}\text { independent } \\
\text { variable }\end{array}$} & $\begin{array}{c}\text { Investment Decisions } \\
\text { (ID) }\end{array}$ & Financial Ability & FA & 4 \\
\cline { 3 - 5 } & Perceived Usefulness & PU & 4 \\
\cline { 3 - 5 } & $\begin{array}{c}\text { Products \& Company } \\
\text { Attributes }\end{array}$ & P\&CA & 4 \\
\cline { 3 - 5 } & $\begin{array}{c}\text { Knowledge \& past } \\
\text { Experiences }\end{array}$ & K\&PE & 4 \\
\hline \multirow{2}{*}{$\begin{array}{c}\text { dependent } \\
\text { variable }\end{array}$} & $\begin{array}{c}\text { Financial Performance } \\
\text { (FP) }\end{array}$ & Gross Profit Margin & GPM & 3 \\
\cline { 3 - 5 } & Return on Investment & ROI & 3 \\
\cline { 3 - 5 } & Return on sales & ROS & 3 \\
\cline { 3 - 5 } & & Share Trade & ST & 3 \\
\hline
\end{tabular}

Source: By the authors

\section{RESULTS}

\subsection{Reliability}

The questionnaire was measured by using the coefficient (Cronbach's alpha). stability measurement of the questionnaire is a very important step in the study, depending on the statistical percentage that will be obtained through the scale and applied to the questionnaire paragraphs used in the study and through the results and percentages shown in the below table, all percentages are more than $70 \%$, as noted in Table (2), the ranges between 0.83 to 0.87 which is higher than the recommended threshold of $\leq 0.70$. so of the questionnaire stability has appeared, and this, in turn, indicates the possibility of using it in the study (Nunally and Bernstein, 1994).

Table (2) : Cronbach's Alpha Coefficient of The Studied Variables

\begin{tabular}{|l|c|c|}
\hline & Main Variables & Cronbach's Alpha \\
\hline 1 & Investment Decision & 0.87 \\
\hline 2 & Financial performance & 0.83 \\
\hline
\end{tabular}

Source : computer output

\subsection{Measurement model}

In this study, a Confirmation Factor (CFA) analysis was performed to perform a model or model evaluation for the purpose of the overall evaluation of the model and to evaluate the reliability of the measured paragraphs. for evaluating the model and measuring its effectiveness, the model was assessed and measured as discriminatory and convergent validity. Discriminatory validity measures the degree of factors that were assumed to be measured and that are not related and not related to reality. "Fornell and Larker's approach" was used to assess discriminant validity (Fornell and Larkers, 1981). The approximate validity of the elements and compounds 


\section{International Journal of Business Management and Economic Review}

Vol. 5, No. 01; 2022

ISSN: 2581-4664

was measured using the combined reliability between the elements and compounds and the average contrast shown (AVE). These results show that the model meets the criteria for assessing convergent validity.

\subsection{The Measurement Model for Investment Decision}

The measurement model fit was assessed by absolute fit measures including observed normed $(2 / \mathrm{df})=11.23$, evaluating the root mean square of approximation $(\mathrm{RMSEA})=0.318$, Comparative Fit Index $(\mathrm{CFI})=0.94, \mathrm{TLI}=81, \mathrm{IFI}=0.94$,

Standardized Root Mean Square Residual (SRMR), Adjusted Goodness of fit (AGFI), Normed Fit Index $(\mathrm{NFI})=0.93$ and Goodness of fit $(\mathrm{GFI})=0.90$. Figure

(1) shown below shows modeling the Measurement model for Investment Decision with a unified path According to the tables $(5,6,7,8)$, results and analyses are at acceptable and good levels. Good fit statistics as the general model fits well with the data and well.(Hair et al., 2010) to ensure that only good items are carried over to the CFA stage of validation. The results from standardized estimates of the normalized data in Figure 1.

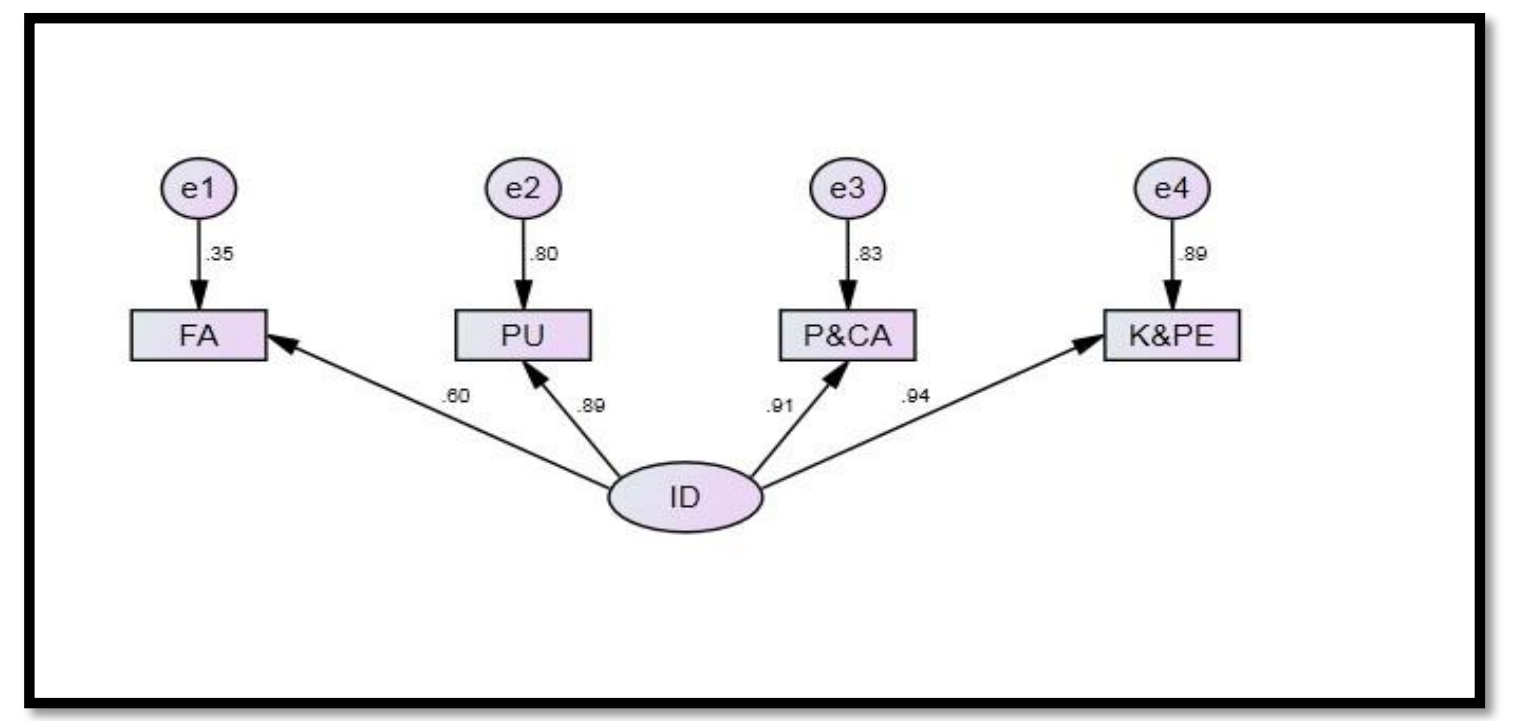

Figure 1: Measurement Model For Investment Decision.

Table (3): The Result of model Fit Index / CMIN

\begin{tabular}{|l|c|c|c|c|c|}
\hline Model & NPAR & CMIN & DF & P & CMIN/DF \\
\hline Default model & 8 & 22.467 & 2 & .000 & 11.234 \\
\hline Saturated model & 10 & .000 & 0 & & \\
\hline Independence model & 4 & 335.135 & 6 & .000 & 55.856 \\
\hline
\end{tabular}




\section{International Journal of Business Management and Economic Review}

Vol. 5, No. 01; 2022

ISSN: 2581-4664

Table (4): The Result of model Fit Index /RMR, GFI

\begin{tabular}{|l|c|c|c|c|c|}
\hline Model & RMR & GFI & & AGFI & PGFI \\
\hline Default model & .162 & .901 & & .506 & .180 \\
\hline Saturated model & .000 & 1.000 & & & \\
\hline Independence model & 1.403 & .395 & & -.008 & .237 \\
\hline
\end{tabular}

Table (5):The Result of model Fit Index / Baseline Comparisons

\begin{tabular}{|l|r|r|r|r|r|}
\hline Model & $\begin{array}{r}\text { NFI } \\
\text { Delta1 }\end{array}$ & $\begin{array}{r}\text { RFI } \\
\text { rho1 }\end{array}$ & $\begin{array}{r}\text { IFI } \\
\text { Delta2 }\end{array}$ & $\begin{array}{r}\text { TLI } \\
\text { rho2 }\end{array}$ & CFI \\
\hline Default model & .933 & .799 & .939 & .813 & .938 \\
\hline Saturated model & 1.000 & & 1.000 & & 1.000 \\
\hline Independence model & .000 & .000 & .000 & .000 & .000 \\
\hline
\end{tabular}

Table (6): The Result of model Fit Index / RMSEA

\begin{tabular}{|l|c|c|c|c|}
\hline Model & RMSEA & LO 90 & HI 90 & PCLOSE \\
\hline Default model & .318 & .208 & .443 & .000 \\
\hline Independence model & .737 & .671 & .805 & .000 \\
\hline
\end{tabular}

\subsection{The measurement model for Financial performance}

The measurement model fit was assessed by absolute fit measures including observed normed $(2 / \mathrm{df})=10.46$, evaluating the root mean square of approximation $(\mathrm{RMSEA})=0.31$, Comparative Fit Index $(\mathrm{CFI})=0.94, \mathrm{TLI}=0.83, \mathrm{IFI}=0.95, \mathrm{P}=$

0.000, Standardized Root Mean Square Residual (SRMR), Adjusted Goodness of fit (AGFI), Normed Fit Index $(\mathrm{NFI})=0.94$ and Goodness of fit $(\mathrm{GFI})=0.90$, Figure (2) shown below shows modeling the Measurement model for investment decision with a unified path According to the tables $(9,10,11,12)$, results and analyses are at acceptable and good levels. Good fit statistics as the general model fits well with the data and well. The results from standardized estimates of the normalized data are in Figure 2.

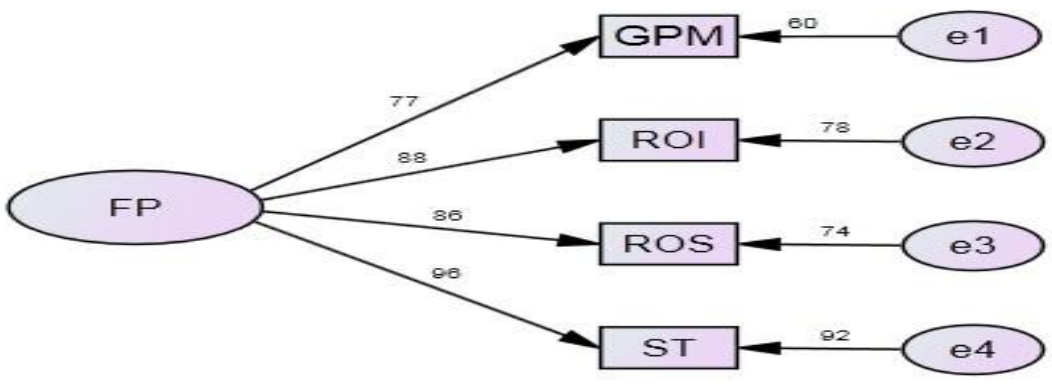

Figure 2 : Measurement Model of Financial performance 
International Journal of Business Management and Economic Review

Vol. 5, No. 01; 2022

ISSN: $2581-4664$

Table (7):The Result of model Fit Index / CMIN

\begin{tabular}{|l|r|r|l|r|r|r|r|}
\hline Model & NPAR & CMIN & & & DF & P & CMIN/DF \\
\hline Default model & 8 & 20.922 & & & 2 & .000 & 10.461 \\
\hline Saturated model & 10 & .000 & & & 0 & & \\
\hline Independence model & 4 & 350.588 & & & 6 & .000 & 58.431 \\
\hline
\end{tabular}

Table (8): The Result of model Fit Index / RMR, GFI

\begin{tabular}{|l|r|r|r|r|}
\hline Model & RMR & GFI & AGFI & PGFI \\
\hline Default model & .067 & .925 & .624 & .185 \\
\hline Saturated model & .000 & 1.000 & & \\
\hline Independence model & 1.309 & .365 & -.058 & .219 \\
\hline
\end{tabular}

Table (9): The Result of model Fit Index / Baseline Comparisons

\begin{tabular}{|l|r|r|r|r|r|}
\hline Model & $\begin{array}{r}\text { NFI } \\
\text { Delta1 }\end{array}$ & $\begin{array}{c}\text { RFI } \\
\text { rho1 }\end{array}$ & $\begin{array}{r}\text { IFI } \\
\text { Delta2 }\end{array}$ & $\begin{array}{r}\text { TLI } \\
\text { rho2 }\end{array}$ & CFI \\
\hline Default model & .940 & .821 & .946 & .835 & .945 \\
\hline Saturated model & 1.000 & & 1.000 & & 1.000 \\
\hline Independence model & .000 & .000 & .000 & .000 & .000 \\
\hline
\end{tabular}

Table (10): The Result of model Fit Index / RMSEA

\begin{tabular}{|l|r|r|r|r|}
\hline Model & RMSEA & LO 90 & HI 90 & PCLOSE \\
\hline Default model & .306 & .196 & .431 & .000 \\
\hline Independence model & .754 & .688 & .822 & .000 \\
\hline
\end{tabular}

\subsection{Relationship Between Investment Decision and Financial performance}

The Relationship Between Investment Decision and Financial performance was assessed by absolute fit measures including some indicts normal need to modification $(2 / \mathrm{df})=4.094$, evaluating the root mean square of approximation $($ RMSEA) $=0.175$, Comparative Fit Index $(\mathrm{CFI})=0.92, \mathrm{TLI}=0.88, \mathrm{IFI}=0.92, \mathrm{P}=0.000$, Standardized Root Mean Square Residual $(\mathrm{SRMR})$, Adjusted Goodness of fit (AGFI=0.71), Normed Fit Index (NFI) $=0.89$ and Goodness of fit $(\mathrm{GFI})=0.85$, Figure (3) shown below shows modeling the Measurement model for Investment Decision with a unified path According tothe tables( 13,14,15,16,17,18), results and analyzes at some indicts acceptable. Good fit statistics as the general model fits but GFI less than 0.90 so need modification model. The results from standardized estimates of the normalized data in Figure 3 


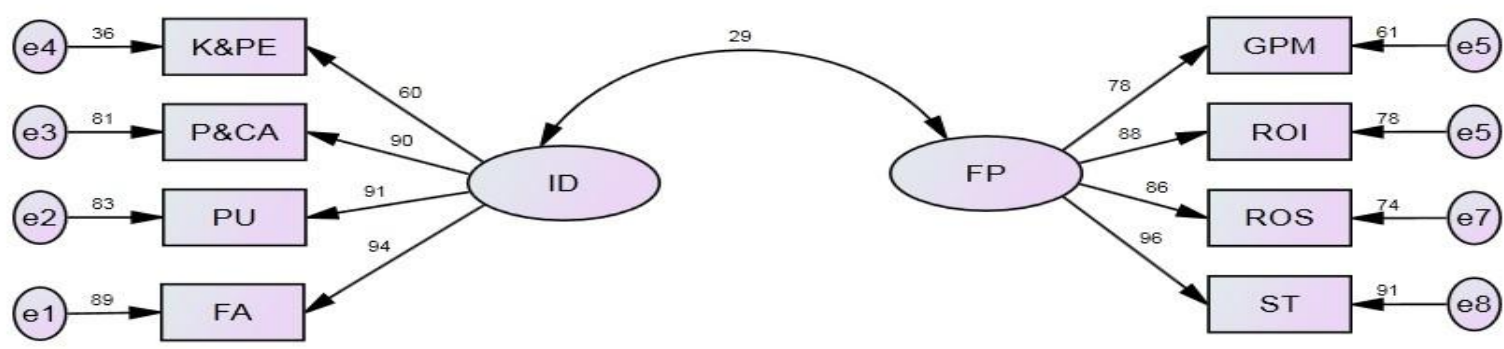

Figure 3: Relationship Between Investment Decision and Financial performance

Table (11):The Result of model Fit Index / CMIN

\begin{tabular}{|l|r|r|r|r|r|}
\hline Model & NPAR & CMIN & DF & P & CMIN/DF \\
\hline Default model & 17 & 77.789 & 19 & .000 & 4.094 \\
\hline Saturated model & 36 & .000 & 0 & & \\
\hline Independence model & 8 & 727.724 & 28 & .000 & 25.990 \\
\hline
\end{tabular}

Table (12): The Result of model Fit Index / RMR, GFI

\begin{tabular}{|l|r|r|r|r|}
\hline Model & RMR & GFI & AGFI & PGFI \\
\hline Default model & .194 & .851 & .717 & .449 \\
\hline Saturated model & .000 & 1.000 & & \\
\hline Independence model & 1.098 & .345 & .158 & .269 \\
\hline
\end{tabular}

Table (13):The Result of model Fit Index / Baseline Comparisons

\begin{tabular}{|l|r|r|r|r|r|}
\hline Model & $\begin{array}{r}\text { NFI } \\
\text { Delta1 }\end{array}$ & $\begin{array}{r}\text { RFI } \\
\text { rho1 }\end{array}$ & $\begin{array}{r}\text { IFI } \\
\text { Delta2 }\end{array}$ & $\begin{array}{r}\text { TLI } \\
\text { rho2 }\end{array}$ & CFI \\
\hline Default model & .893 & .842 & .917 & .876 & .916 \\
\hline Saturated model & 1.000 & & 1.000 & & 1.000 \\
\hline Independence model & .000 & .000 & .000 & .000 & .000 \\
\hline
\end{tabular}

Table (14): The Result of model Fit Index / RMSEA

\begin{tabular}{|l|r|r|r|r|}
\hline Model & RMSEA & LO 90 & HI 90 & PCLOSE \\
\hline Default model & .175 & .136 & .216 & .000 \\
\hline Independence model & .497 & .467 & .529 & .000 \\
\hline
\end{tabular}


Vol. 5, No. 01; 2022

ISSN: $2581-4664$

\section{Table (15):The Result of model Fit Index / Regression Weights}

\begin{tabular}{|c|l|l|r|r|r|r|r|}
\hline & & & Estimate & S.E. & C.R. & P & Label \\
\hline FA & $<---$ & ID & 1.000 & & & & \\
\hline PU & $<---$ & ID & 1.424 & .091 & 15.653 & $* * *$ & \\
\hline P\&CA & $<---$ & ID & 1.342 & .088 & 15.165 & $* * *$ & \\
\hline K\&PE & $<---$ & ID & 1.119 & .159 & 7.023 & $* * *$ & \\
\hline GPM & $<---$ & FP & 1.000 & & & & \\
\hline RIO & $<---$ & FP & 1.166 & .116 & 10.063 & $* * *$ & \\
\hline ROS & $<---$ & FP & 1.322 & .136 & 9.696 & $* * *$ & \\
\hline ST & $<---$ & FP & 1.493 & .136 & 11.014 & $* * *$ & \\
\hline
\end{tabular}

Table (16): The Result of model Fit Index / Standardized Regression Weights Estimate

\begin{tabular}{|c|l|l|l|}
\hline & & & Estimate \\
\hline FA & $<---$ & ID & .941 \\
\hline PU & $<---$ & ID & .908 \\
\hline P\&CA & $<---$ & ID & .897 \\
\hline K\&PE & $<---$ & ID & .600 \\
\hline GPM & $<---$ & FP & .779 \\
\hline RIO & $<---$ & FP & .883 \\
\hline ROS & $<---$ & FP & .859 \\
\hline ST & $<---$ & FP & .956 \\
\hline
\end{tabular}

The model retest with modification based on model indicates was assessed by absolute fit measures including observed normed $(2 / \mathrm{df})=2.13$, evaluating the root mean square of approximation $($ RMSEA $)=0.106$, Comparative Fit Index $(\mathrm{CFI})=0.97, \mathrm{TLI}=0.95, \mathrm{IFI}=0.97, \mathrm{P}=$ 0.004, Standardized Root Mean Square Residual (SRMR), Adjusted Goodness of fit (AGFI=0.71) , Normed Fit Index (NFI) $=0.92$ and Goodness of fit $(\mathrm{GFI})=0.92$,. Figure (3) shown below shows modeling the Measurement model Investment Decision with a unified path According to the tables $(19,20,21,22)$, results and analyzes at acceptable and good levels. Good fit statistics as the general model fits well with the data and well. The results from standardized estimates of the normalized data in Figure 4. 
Vol. 5, No. 01; 2022

ISSN: $2581-4664$

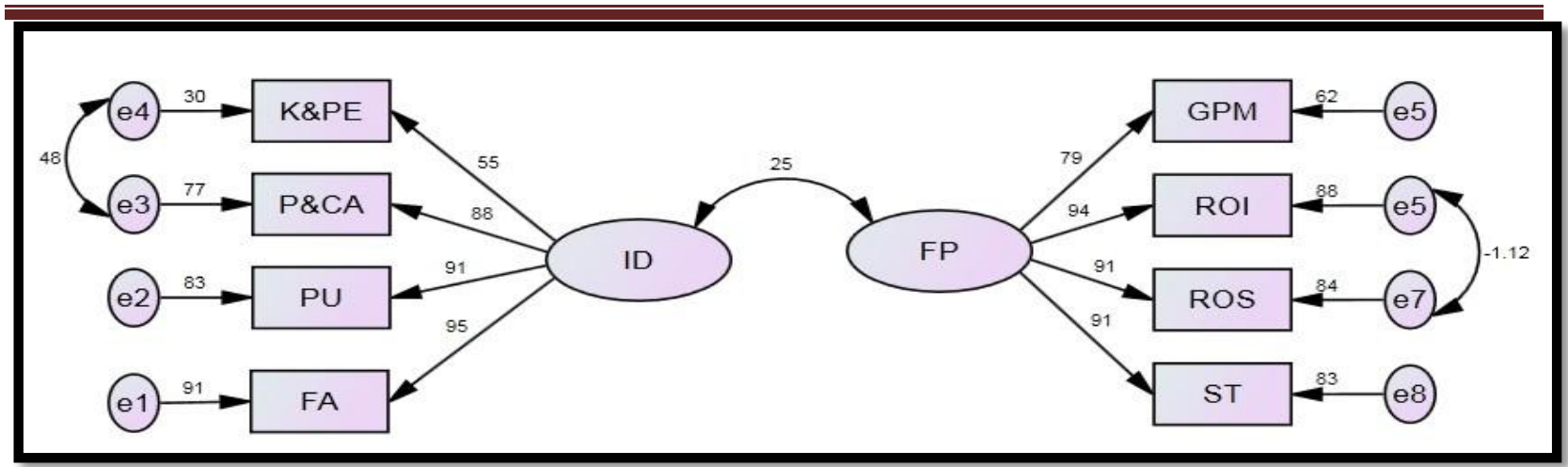

Figure 4 : Relationship Between Investment Decision and Financial Performance After Modification

Table (17): The Result of model Fit Index / CMIN

\begin{tabular}{|l|rrrrr|}
\hline Model & NPAR & CMIN & DF & P & CMIN/DF \\
\hline Default model & 19 & 36.225 & 17 & .004 & 2.131 \\
Saturated model & 36 & .000 & 0 & & \\
Independence model & 8 & 727.724 & 28 & .000 & 25.990 \\
\hline
\end{tabular}

Table (18): The Result of model Fit Index / RMR, GFI

\begin{tabular}{|l|rrrr|}
\hline Model & RMR & GFI & AGFI & PGFI \\
\hline Default model & .200 & .923 & .838 & .436 \\
Saturated model & .000 & 1.000 & & \\
Independence model & 1.098 & .345 & .158 & .269 \\
\hline
\end{tabular}

Table (19): The Result of model Fit Index / Baseline Comparisons

\begin{tabular}{|l|rrrrr|}
\hline Model & $\begin{array}{r}\text { NFI } \\
\text { Delta1 }\end{array}$ & $\begin{array}{r}\text { RFI } \\
\text { rho1 }\end{array}$ & $\begin{array}{r}\text { IFI } \\
\text { Delta2 }\end{array}$ & $\begin{array}{r}\text { TLI } \\
\text { rho2 }\end{array}$ & CFI \\
\hline Default model & .950 & .918 & .973 & .955 & .973 \\
Saturated model & 1.000 & & 1.000 & & 1.000 \\
Independence model & .000 & .000 & .000 & .000 & .000 \\
\hline
\end{tabular}

Table (20): The Result of model Fit Index / RMSEA

\begin{tabular}{|l|rrrr|}
\hline Model & RMSEA & LO 90 & HI 90 & PCLOSE \\
\hline Default model & .106 & .057 & .154 & .032 \\
Independence model & .497 & .467 & .529 & .000 \\
\hline
\end{tabular}

H1- Is there a relationship between Investment Decisions and Financial Performance in Rasheed bank? According to the table $(91,20)$ shown in the below, which according to the value shows that the hypothesis that there is a strong relationship between the two variables is the Investment Decisions and the Financial Performance in Rasheed bank. 
International Journal of Business Management and Economic Review

Vol. 5, No. 01; 2022

ISSN: $2581-4664$

Table (21):The Result of model Fit Index / Covariance's

\begin{tabular}{|l|l|l|c|r|r|r|r|}
\hline & & & Estimate & S.E. & C.R. & P & Label \\
\hline ID & $\langle-->$ & FP & .285 & .124 & 2.308 & .021 & \\
\hline e3 & $\langle-->$ & e4 & .640 & .167 & 3.839 & $* * *$ & \\
\hline e6 & $\langle--\rangle$ & e7 & -.345 & .078 & -4.426 & $* * *$ & \\
\hline
\end{tabular}

Table (22): The Result of model Fit Index /Correlations

\begin{tabular}{|c|c|c|c|}
\hline & & & Estimate \\
\hline ID & $\langle->$ & FP & .247 \\
\hline e3 & $<->$ & e4 & .485 \\
\hline e6 & $\langle->$ & e7 & -1.122 \\
\hline
\end{tabular}

\section{6: The affect Investment Decisions on Financial Performance.}

H2- Is there an Investment Decisions that affects the Financial Performance in Rasheed bank?

According to the table $(21,22)$ shown in the below, which according to the value shows that the hypothesis that there is Investment Decisions effect on Financial Performance in Rasheed bank.

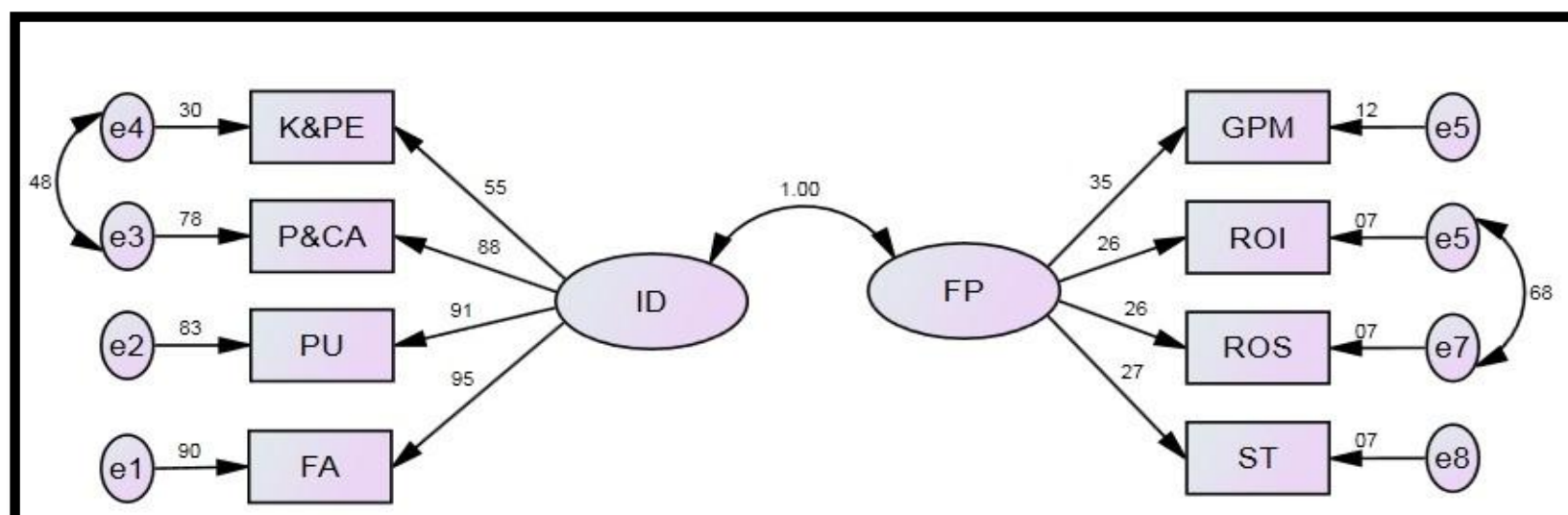

Figure 5 : Relationship Between Investment Decisions And Financial Performance After processes. 
Vol. 5, No. 01; 2022

Table (23): The Result of model Fit Index Regression Weights

\begin{tabular}{|c|c|c|c|c|c|c|}
\hline & & Estimate & S.E. & C.R. & $\bar{P}$ & Label \\
\hline & $\begin{array}{l}--- \\
\text { ID }\end{array}$ & .419 & .117 & 3.567 & $* * *$ & \\
\hline$K \& P$ & $<---\quad$ ID & 1.000 & & & & \\
\hline $\mathrm{P} \& \mathrm{C}$ & $<--\quad$ ID & 1.411 & .089 & 15.920 & $* * *$ & \\
\hline $\mathrm{PU}$ & $<---\quad$ ID & 1.307 & .089 & 14.749 & $* * *$ & \\
\hline FA & $<---\quad$ ID & 1.015 & .164 & 6.202 & $* * *$ & \\
\hline ST & $<---\quad$ FP & 1.000 & & & & \\
\hline ROS & $<---\quad$ FP & .768 & .363 & 2.116 & .034 & \\
\hline ROI & $<---\quad F P$ & .913 & .426 & 2.144 & .032 & \\
\hline GPM & $<---\quad F P$ & .958 & .437 & 2.192 & .028 & \\
\hline
\end{tabular}

Table (24):The Result of model Fit Index Covariance's

\begin{tabular}{|c|c|c|c|c|c|}
\hline & Estimate & S.E. & C.R. & $\bar{P}$ & Label \\
\hline \begin{tabular}{|lll}
$\mathrm{e} 3$ & $\langle->$ & $\mathrm{e} 4$
\end{tabular} & .619 & .164 & 3.766 & $* * *$ & \\
\hline e6 & 1.384 & .247 & 5.613 & $* * *$ & \\
\hline
\end{tabular}

\section{CONCLUSION:}

This paper sheds light on the most important results of its reached by testing the data collected from a sample that was taken from the Rasheed bank of Iraq it was analyzed in the (AMOS) program and through the results shown in the tables above, we note that there is a strong impact relationship between Investment Decisions and the Financial Performance and how that, in turn, affects bank profits through the following :

1- Estimating the amount of the risk and return level that can be caused by the invested assets.

2- The optimal selection of the invested assets under the Umbrella of the trade-off between return and risk when an investment decision is made.

3- The corporate commitment to developing and enhancing the financial intelligence of individuals involved in the task of making investment decisions.

4- The necessity of defining and paying attention to the financial performance indicators because they reflect the financial position of the company.

\section{REFERENCES}

1.Aburas, R., \& Ab Hamid, N. R. A Construct Validity of Investment Decision in the Banking Sector in Libya (A Structural Equation Modeling Approach).

2.Agrawal, S., Singh, R. K., \& Murtaza, Q. (2016). Triple bottom line performance evaluation of reverse logistics. Competitiveness Review.

3.Barringer, R. B., \& Ireland, R., D. (2006) . Entrepreneurship, successfully launching new 


\section{International Journal of Business Management and Economic Review}

Vol. 5, No. 01; 2022

ISSN: 2581-4664

ventures (2nd ed.). Pearson education.

4.Bierman, H. Jr., \& Smidt, S. (1993). The capital budgeting decision: Economic analysis of investment projects (8th ed.). Upper Saddle River, NJ: Prentice- Hall.

5.Brealey, R. A., \& Myers, S. C. (2003). Principles of corporate finance. New York, NY: Tata McGraw-Hill.

6.Brigham, E. F., \& Gapenski, L. C. (1997). Financial Management: Theory and Practice (Eight Edit). The Dryden Press, Harcourt Brace College Publishers.

7.Brigham, E. F., \& Houston, J. F. (2006). Fundamentals of Financial Management= DasarDasar Manajemen Keuangan, Buku 1. Alih Bahasa, Ali Akbar Yulianto (10th ed.). Jakarta: Salemba Empat.

8.Byrne, B.M. (2010). Structural Equation Modeling with AMOS: Basic Concepts, Applications, and programming routledge.

9.De Giovanni, P., \& Vinzi, V. E. (2012). Covariance versus component-based estimations of performance in green supply chain management. International Journal of Production Economics, 135(2), 907-916.

10.Fornell, C., \& Larcker, D. F. (1981). Structural equation models with unobservable variables and measurement error: Algebra and statistics.

11.Gitman, L. J., Juchau, R., \& Flanagan, J. (2015). Principles of managerial finance. Pearson Higher Education AU.

12.Hair, J., Black, W.C., Babin, B. J., \& Anderson, R.E. (2010). Multivariate Data Analysis (7th Edition). NJ: Prentice-Hall Publication.

13.Harjito, A., \& Martono. (2013). Manajemen Keuangan (Editi Ke-2). Yogyakarta: Ekonisia, Kampus Fakultas Ekonomi, Universitas Islam Indonesia.

14.Hidayat, R. (2010). Investment Decisions and Financial Constraints: Empirical Studies.

15.Martono, \& Harjito, A. (2003). Manajemen Keuangan, Teori dan Aplikasi. Jakarta: Erlangga.

16.Mintzberg, H., Raisinghani, D., \& Theoret, A. (1976). The structure of

„unstructured"e decision processes. Administrative Science Quarterly, 21(2), 247-275.

17.Mishkin, F. S. (2004). Overhead Transparencies to Accompany The Economics of Money, Banking, and Financial Markets. Pearson/Addison Wesley.

18. Nunnally, J. C., \& Bernstein, I. H. (1994). Validity. Psychometric theory, 3, 99-132.

19.Pandey I.M (2008). Financial Management: Vikas Publishing House Pvt Ltd. New Delhi, India.

20.Riyanto, B. (2013). Dasar-Dasar Pembelanjaan Perusahaan (Edisi 4, C). Yogyakarta: BPFE UGM.

21.Riyanto, B. (2013). Dasar-Dasar Pembelanjaan Perusahaan (Edisi 4, C). Yogyakarta: BPFE UGM.

22.Ross, S. A. (2002). Fundamentals Of Corporate Finance (Sixth Edit). McGraw- Hill Irwin.

23.Ross, S. A., Westerfield, R. W., Jaffe, J. F., \& Jordan, B. D. (2015). Corporate Finance: Core Principles And Applications (Fourth Edi). New York: McGraw- Hill Education.

24.Ross, S. A., Westerfield, R. W., Jaffe,A.(2007). Corporate Finance., 6 th edition, Mc Graw Hill , NewYourk. 
International Journal of Business Management and Economic Review

Vol. 5, No. 01; 2022

ISSN: 2581-4664

25.Ross, S. A., Westerfield, R., \& Jordan, B. D. (2014). Fundamentals of corporate finance. New York, NY, USA: Irwin.

26.Ross, S. A., Westerfield, R., Jordan, B. D., \& Biktimirov, E. N. (2008). Essentials of corporate finance (p. 656). McGraw-Hill/Irwin.

27.Sears, R. S., \& Trennepohhl, G. L. (1993). Investment management (1st ed.), Dryden press.

28.Simeyo O, Benard O, Patrick O, and Francis M (2013). An assessment of government financial regulations on financial performance of SACCOs in Kisii Central.

29.Slagmulder, R. (1997). Using management control systems to achieve alignment between strategic investment decisions and strategy. Management Accounting Research, 8(1), 103-139.

30.Sumarsono, H. d. (2013). Effect of Funding Decisions, Dividend Policy and Company Growth on Company Values. Journal of Equilibrium, Vol. 10.No01. Pp. 36-46.

31.Zehir, C. and Ozsahin, O. (2008), "A field research on the relationship between strategic decision-making speed and innovation performance in the case of Turkish large-scale firms", Management Decision, Vol. 46 No. 5, p. 709-724.

32.Zvi, B., Alex, K., \& Allan, J, M. (2004). Essentials of investments (5th ed.). New York :Irwin. 